\title{
Mapping the fern Blechnum heringeri (Blechnaceae, Polypodiopsida): recording the geographical distribution, ecological preferences and reporting a new record in northeastern Brazil
}

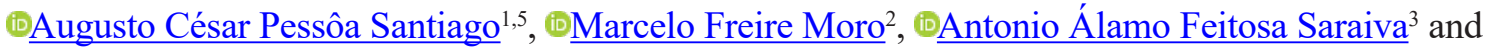 \\ (Dinícius Antonio de Oliveira Dittrich ${ }^{4}$
}

Received: 12 September 2018; accepted: 17 Juny 2019

How to cite: Santiago, A.C.P., Moro, M.F., Saraiva, A.A.F. \& Dittrich, V.A.O. 2019. Mapping the fern Blechnum heringeri (Blechnaceae, Polypodiopsida): recording the geographical distribution, ecological preferences and reporting a new record in northeastern Brazil. Hoehnea 46: e852018. http://dx.doi.org/10.1590/2236-8906-85/2018.

ABSTRACT - (Mapping the fern Blechnum heringeri (Blechnaceae, Polypodiopsida): recording the geographical distribution, ecological preferences and reporting a new record in northeastern Brazil). Blechnum heringeri Brade is an endemic species from Brazil previously considered vulnerable. Until recently, there was a very limited number of records for this species, all from the Cerrado Phytogeographical Domain in central Brazil. Subsequent studies have reported its occurrence in the rupestrian grasslands (campos rupestres) on the "cangas", within the Amazonian Domain. Here we present the first record of $B$. heringeri for northeastern Brazil, from an enclave of cerrado vegetation in the middle of the Caatinga Domain (Ceará State). This new record significantly extends the distributional range of the species, about 1,000 km from the known records in the Amazon and Cerrado Phytogeographical Domains. We also show that the species is associated with open vegetation or the transition between open vegetation and riverine forests, being recorded in cerrado vegetation, riverine forests associated with the cerrado, cerrado enclaves in the Caatinga and Amazonian Domains, and Amazonic campos rupestres on "canga". Keywords: Araripe, Ceará, endemism, ferns

RESUMO - (Mapeando a distribuição da samambaia Blechnum heringeri (Blechnaceae, Polypodiopsida): registro da sua distribuição geográfica, preferências ecológicas e um novo registro no Nordeste brasileiro). Blechnum heringeri Brade é uma espécie endêmica do Brasil anteriormente considerada vulnerável. Até pouco tempo atrás, o número de registros dessa espécie era muito limitado e restrito ao Domínio Fitogeográfico do Cerrado, no Brasil central. Coletas recentes registraram a espécie nos campos rupestres sobre cangas, no Domínio da Amazônia. Neste trabalho, apresentamos um novo registro de $B$. heringeri em um encrave de vegetação de cerrado dentro do Domínio da Caatinga, no Nordeste do Brasil (Estado do Ceará). Este novo registro estende significativamente a área de distribuição da espécie, distando cerca de $1.000 \mathrm{~km}$ dos registros nos Domínios Fitogeográficos do Cerrado e Amazônico. Os dados evidenciam a sua associação com vegetações abertas: nominalmente vegetação de cerrado, encraves de cerrado em meio à Caatinga e à Amazônia, e campos rupestres sobre canga na Amazônia ou ambientes de transição com florestas ribeirinhas.

Palavras-chave: Araripe, Ceará, endemismo, samambaias

Blechnaceae Newman is a cosmopolitan, monophyletic fern family comprising 24 genera and ca. 265 species with some distinctive features: sori on both sides of the costae borne along commisural, subcostal veins, introrse indusia (rarely absent) and three or more vascular bundles in the stipe (except
Lorinseria areolata L., which has only two bundles) (Rothfels et al. 2012, Sundue \& Rothfels 2014, Gasper et al. 2016, 2017). The veins in Blechnum are generally free, but three species have partially anastomosing veins, all of them endemic to Brazil: B. areolatum V.A.O. Dittrich \& Salino, B. heringeri

\footnotetext{
1. Universidade Federal de Pernambuco, Núcleo de Biologia, 55608-680 Vitória de Santo Antão, PE, Brasil

2. Instituto de Ciências do Mar (Labomar), Universidade Federal do Ceará, 60165-081 Fortaleza, CE, Brasil

3. Universidade Regional do Cariri, Departamento de Ciências Físicas e Biológicas, 63105000 Crato, CE, Brasil

4. Universidade Federal de Juiz de Fora, Departamento de Botânica, 36036-900 Juiz de Fora, MG, Brasil

5. Corresponding author: augustosantiago@hotmail.com
} 
Brade, and B. longipilosum V.A.O. Dittrich \& Salino (Dittrich et al. 2012, 2015). Blechnum areolatum and $B$. longipilosum are restricted to the Amazonian Phytogeographical Domain (Amazon hereafter), whereas Blechnum heringeri occurs in the Amazon and in the Cerrado Phytogeographical Domain (Cerrado hereafter).

During fieldwork in the Chapada do Araripe (Ceará State, Northeastern Brazil), in the central part of the Caatinga Phytogeographical Domain (Caatinga hereafter), we collected some specimens of Blechnum heringeri from two small populations, both with less than 20 individuals. We thus report here the first occurrence of Blechnum heringeri in the Caatinga Domain, associated with enclaves of savanna, and provide a global map of the known distribution of the plant. The identification and the distribution of the species were based on recent reviews and floristic studies focused on the family Blechnaceae in Brazil (Dittrich et al. 2012, 2015, Gasper et al. 2016, Dittrich \& Gasper 2017, Salino et al. 2017).

Blechnum heringeri Brade Sellowia 18: 87, t. 1, 2. 1966.

Type: BRAZIL. Minas GeRAIs: Paracatu, 2-IV-1963, E.P. Heringer s.n. (holotype HB 34030!, isotype K000633401!).

Figure 1

Description and illustration: Dittrich et al. 2015

Material examined: BRAZIL: CEARÁ: Crato, APA Araripe, Encosta do Clube Serrano, $7^{\circ} 16^{\prime} 01$ 'S, $39^{\circ} 27^{\prime} 44^{\prime \prime} \mathrm{W}, 720 \mathrm{~m}, 2-\mathrm{VI}-2010$, A. Santiago \& A.A.F. Saraiva 1050 (UFP); Crato, Floresta Nacional do Araripe, $7^{\circ} 16^{\prime} 36^{\prime}$ 'S, 39²7’03”'W, 700 m, 17-V-2011, A. Santiago et al. 1200 (UFP).

Additional material examined: BRAZIL: PARÁ. Canaã dos Carajás, Serra do Tarzan, 606'19'S, 5007'00'W, 540 m, 9-II-2012, A. Salino 15151 (BHCB); Monte Alegre, Serra do Itauajuri, $1^{\circ} 51.01^{\prime} 08^{\prime}$ 'S, 54⒉42'04”'W, 2-VII-2010, J.P. Pallos \& R.M. Pietrobom 64 (HUEFS); Parauapebas, Serra do Rabo, 6¹7'03"S, 4955'02'W, 600 m, 16-XII-2010, N.F.O. Mota et al. 1921 (BHCB). Minas Gerais. Paracatu, Reserva do Acangaú, Capão da Guariroba, 17'12'14.5”S, 4706'54.8”'W, 700 m, 4-II-2006, A. Salino et al. 10743 (BHCB); São Roque de Minas, Parque Nacional da Serra da Canastra, Capão Forro, 20¹5'11.9'S, 46²4'26.1'W, 970 m, 31-I-2007, A.

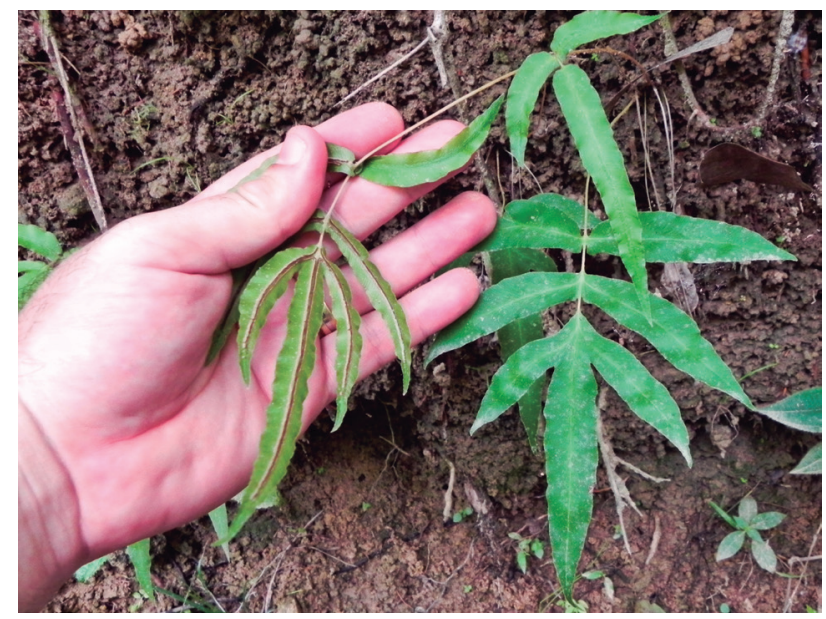

Figure 1. General habit of Blechnum heringeri.

Salino et al. 11593 (BHCB). GoIÁs. Alto Paraíso de Goiás, Santuário do Raizama, 23-I-2013, G. Heringer \& A.M. Silva s.n. (CESJ 61864); Luziânia, Margem direita do Rio Alagado, 16¹5'23”'S, 48 $111^{\prime} 35^{\prime \prime} \mathrm{W}$, 827 m, 12-IV-2005, G. Pereira-Silva 9953 (CEN). Distrito Federal. Riacho Fundo, Fazenda Sucupira (Regão entre Recanto das Emas e Riacho Fundo), 15'51'52”S, 4752'10”'W, 1150 m, 17-IX-1999, C.E. Rodrigues Júnior 1377 (HEPH).

Distribution: Brazil: Pará (Amazon); Minas Gerais, Goiás, and Distrito Federal (Cerrado); Ceará (Caatinga) (figure 2). In the Caatinga (figure 3) the two populations we found were located in the Chapada do Araripe plateau. One of these populations was in an enclave of cerrado vegetation on the edge of "Floresta Nacional do Araripe", whereas the other was in a nearby site, in a habitat that harbored a transitional area between cerrado vegetation and humid forest in the plateau (Moro et al. 2015). In the Amazon, the species was associated both with the campos rupestres on canga in Carajás and with an "igarapé" (seasonally flooded Amazonian forestPallos 64 in MG herbarium) on the foothills of a mountain (Serra do Itauajuri), where cerrado and campo rupestre vegetation abound on the mountain top (Pallos et al. 2016). Although usually associated only with rainforests, the Amazon domain also harbors other vegetation types. Scattered enclaves of cerrado savannas, for example, are found in the middle of the Amazonian forests (Ratter et al. 2003). Also, the higher parts of the Carajás mountains harbor ironore substrates where patches of grasslands flourish on the mountaintops, surrounded by rainforests in 


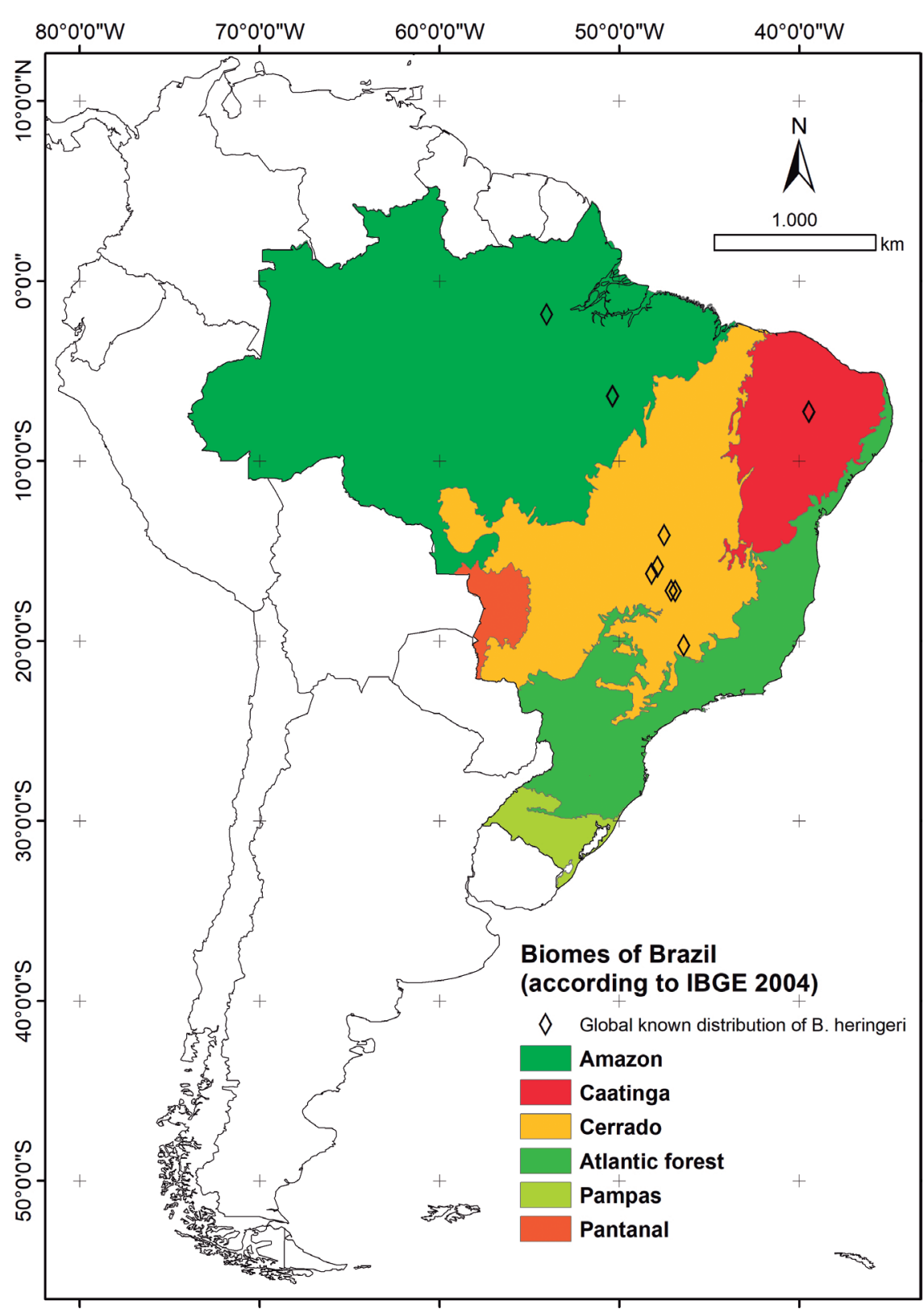

Figure 2. Global known distribution of Blechnum heringeri, showing its presence in three Brazilian phytogeographic domains, yet always associated with or close to open vegetation enclaves of cerrado or campos rupestres (rupestrian grasslands on cangas) in each domain.

the lowlands. This happens because the "canga" substrate on these mountaintops are not appropriate for the establishment of the roots of trees in most sites, providing open habitats in a region mostly composed by dense forests (see Viana et al. 2016 and Mota et al. 2018 for more information about the open vegetation of canga in the Carajás mountaintops).

Blechnum heringeri has an ecological preference for areas of open vegetation of cerrado and campos rupestres, with a new record associated with these habitats in both the core of the Cerrado or in disjunct sites of open vegetation within Amazon and Caatinga, which are geographically distant from the Cerrado (figure 2; figure 3). In the Chapada do Araripe plateau, $B$. heringeri occurs in a moist ravine area at the edge of a cerrado vegetation enclave within the Caatinga (figure 3).

The Caatinga Domain comprises two main types of vegetation: the caatinga sensu stricto, on the crystalline peneplains of the Depressão Sertaneja 

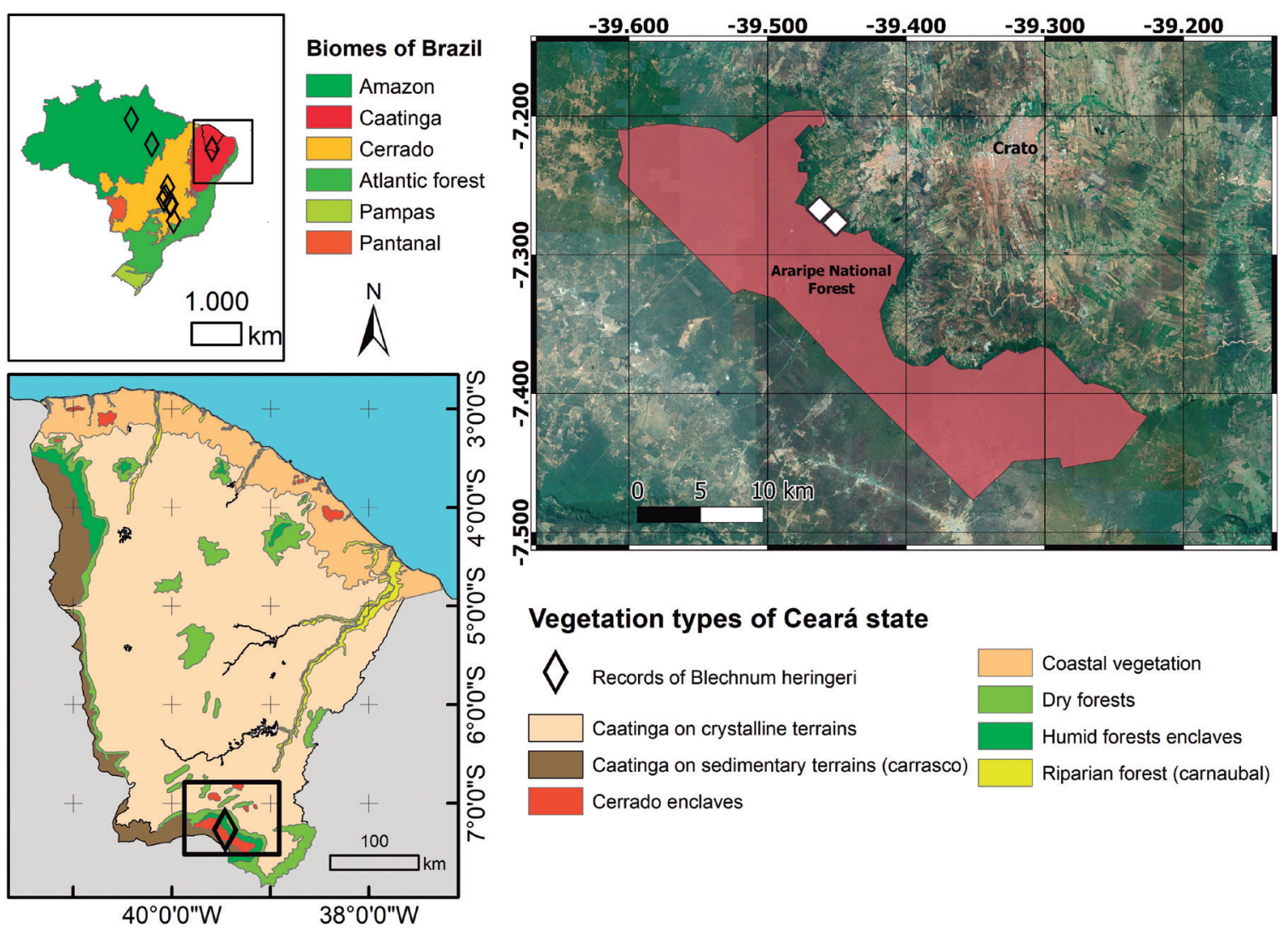

\section{Vegetation types of Ceará state}

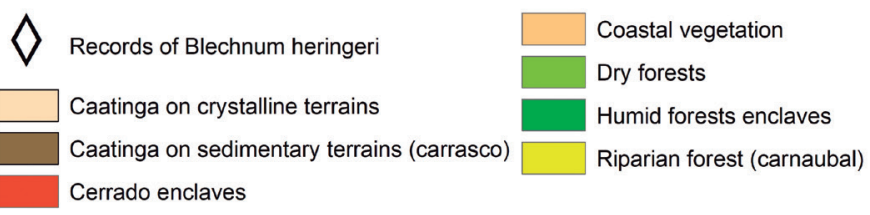

Figure 3. New records of Blechnum heringeri in the Caatinga Domain, Ceará State, northeastern Brazil.

lowlands, and the sandy caatinga (or carrasco) from the sandy terrains of the sedimentary basins of the region (Ab'Sáber 1974, Moro et al. 2015, 2016). However, the heterogeneity of geomorphology and climates also result in the occurrence of enclaves of other vegetation types within the Caatinga. The most typical of these enclaves comprehend patches of wet forests that occur in the more humid windward sides of mountains in the region, when those mountains are high enough to promote orographic rains, and the patches of cerrado vegetation, normally associated with the top of plateaus among a matrix of caatinga (Moro et al. 2016). Two areas where extensive cerrado vegetation enclaves are found inside the Caatinga are the Araripe plateau in Ceará (Figueiredo 1997, Moro et al. 2015), where the occurrence of this species is now confirmed, and the Chapada Diamantina highlands in Bahia (Juncá et al. 2005).

These new records in the Chapada do Araripe were made over one thousand kilometers away from the records in the Amazon and Cerrado Domains (figure 2). Using the GeoCAT online software (http://geocat.kew. org/) (Bachman et al. 2011), we calculated the Extent of Occurrence (EOO) to be $1,411,816.582 \mathrm{~km}^{2}$, which corresponds to the category of Least Concern. When this discontinuity in distribution is taken into account using the Area of Occupancy with a $2 \mathrm{~km}$ cell in GeoCAT (Bachman et al. 2011), the total AOO was only 44.000 $\mathrm{km}^{2}$ deeming the species as Endangered category (IUCN 2016). This agrees with a previous evaluation made by Dittrich et al. (2013), who considered this species to be vulnerable. While the Redbook of Endangered Plant Species of Brazil (Martinelli \& Moraes 2013) reported only four known occurrences in a small area in central Cerrado a few years ago, we show here a much wider distribution, what reduces concern about the possibility of immediate extinction. We made a reassessment of the species following the IUCN criteria and consider this species as Least Concern due to its large geographical distribution and its confirmed occurrence in Conservation Units in different Brazilian states.

Nevertheless, the ecosystems where Blechnum heringeri occurs are subjected to a huge human pressure: Cerrado has lost half of its area due to agricultural expansion in the $20^{\text {th }}$ century (Brazil 2015); the cangas of Carajás, within the Amazon, is one of the major mining districts for iron-ore in the world (Viana et al. 2016); and the Araripe Plateau in Caatinga is suffering deforestation for a number of 
reasons including cattle raising, illegal logging and limestone mining for ornamental stones (pers. obs.). Fortunately, the species is recorded in three protected areas: the Carajás National Forest, Serra da Canastra National Park, and Araripe National Forest. But areas with similar habitats around those nature reserves are being fragmented and destroyed by agriculture, cattle raising and mining (Dittrich et al. 2013).

The readers can download the electronic spreadsheet with all known records of Blechnum heringeri, the maps with the recorded distribution of the species, and the KML files (for reading the data on Google Earth or other GIS) of the species occurrence and $\mathrm{EOO} / \mathrm{AOO}$ here: https://doi.org/10.6084/m9.figshare.7409570.

\section{Acknowledgments}

We thank the Universidade Federal de Pernambuco (Pró-Reitoria de Assuntos Acadêmicos) for the financial support for field classes. We also thank Alexandre Salino, Julieta Pallos, and Gustavo Heringer for information on the collecting localities of some populations of Blechnum heringeri.

\section{Literature cited}

Ab'Sáber, N.A. 1974. O domínio morfoclimático semiárido das Caatingas brasileiras. Geomorfologia 43: 1-39.

Bachman, S., Moat, J., Hill, A.W., de la Torre, J. \& Scott, B. 2011. Supporting red list threat assessments with GeoCAT: Geospatial conservation assessment tool. Zookeys 150: 117-126.

Brazil, Ministry of the Environment. 2015. Fifth National Report to the Convention on Biological Diversity: Brazil. Ministry of the Environment, Brasília.

Dittrich, V.A.O., Salino, A. \& Almeida, T.E. 2012. Two new species of the fern genus Blechnum with partially anastomosing veins from Northern Brazil. Systematic Botany 37: 38-42.

Dittrich, V.A.O. \& Gasper, A.L. 2017. Blechnaceae. In: Flora do Brasil 2020 (em construção). Jardim Botânico do Rio de Janeiro. Available in http://floradobrasil. jbrj.gov.br/reflora/floradobrasil/FB90785 (access in 18-XII-2017).

Dittrich, V.A.O., Salino, A. \& Monteiro, R. 2015. The Blechnum occidentale (Blechnaceae, Polypodiopsida) species group in southern and southeastern Brazil. Phytotaxa 231: 201-229.

Dittrich, V.A.O., Valente, A.S.M., Fernandez, E.P., Monteiro, N.P. \& Prieto, P.V. 2013. Blechnaceae. In: G. Martinelli \& M.A. Moraes (orgs.). Livro vermelho da flora do Brasil. Andrea Jakobsson/Instituto de Pesquisas Jardim Botânico do Rio de Janeiro, Rio de Janeiro, pp. 313-314.
Figueiredo, M.A. 1997. A cobertura vegetal do Ceará (Unidades Fitoecológicas). In: Atlas do Ceará. Governo do Estado do Ceará/Ed. IPLANCE, Fortaleza.

Gasper, A.L., Dittrich, V.A.O., Smith, A.R. \& Salino, A. 2016. A classification for Blechnaceae (Polypodiales: Polypodiopsida): New genera, resurrected names, and combinations. Phytotaxa 275: 191-227.

Gasper, A.L., Almeida, T.E., Dittrich, V.A.O., Smith, A.R. \& Salino, A. 2017. Molecular phylogeny of the fern family Blechnaceae (Polypodiales) with a revised genus level treatment. Cladistics 33: 429-446.

Juncá, F.A., Funch, L. \& Rocha, W. 2005. Biodiversidade e conservação da Chapada Diamantina. Ministério do Meio Ambiente, Brasília.

Martinelli, G. \& Moraes, M.A. 2013. Livro vermelho da flora do Brasil. Centro de Conservação Nacional da Flora, Rio de Janeiro.

Moro, M.F., Macedo, M.B., Moura-Fé, M.M., Castro, A.S.F. \& Costa, R.C. 2015. Vegetação, unidades fitoecológicas e diversidade paisagística do estado do Ceará. Rodriguésia 66: 717-743.

Moro, M.F., Nic Lughadha, E., de Araújo, F.S. \& Martins, F.R. 2016. A phytogeographical metaanalysis of the Semiarid Caatinga Domain in Brazil. The Botanical Review 82: 91-148.

Mota. N.F.O., Watanabe, M.T.C., Zappi, D.C., Hiura, A.L., Pallos, J., Viveros, R.S., Giulietti, A.M. \&Viana, P.L. 2018. Cangas da Amazônia: a vegetação única de Carajás evidenciada pela lista de fanerógamos. Rodriguésia 69: 1435-1488.

Pallos, J., Góes-Neto, L.A.A., Costa, J.M., Souza, F.S. \& Pietrobom, M.R. 2016. Licófitas e samambaias da Serra do Itauajuri, município de Monte Alegre, Pará, Brasil. Rodriguésia 67: 997-1009.

Ratter J.A., Bridgewater, S. \& Ribeiro, J.F. 2003. Analysis of the floristic composition of the Brazilian cerrado vegetation III: comparison of the woody vegetation of 376 areas. Edinburgh Journal of Botany 60: 57-109.

Rothfels, C.J., Sundue, M.A., Kuo, L.Y., Larsson, A., Kato, M., Schuettpelz, E., \& Pryer, K.M. 2012. A revised family-level classification for eupolypod II ferns (Polypodiidae: Polypodiales). Taxon 61: 515-533.

Salino, A., Arruda, A.J. \& Dittrich, V.A.O. 2017. Flora das cangas da Serra dos Carajás, Pará, Brasil: Blechnaceae. Rodriguésia 68: 883-841.

Sundue, M.A. \& Rothfels, C.J. 2014. Stasis and convergence characterize morphological evolution in eupolypod II ferns. Annals of Botany 113: 35-54.

Viana, P.L., Mota, N.F.O., Gil, A.S.B., Salino, A., Zappi, D.C., Harley, R.M., Ilkiu-Borges, A.L., Secco, R.S., Almeida, T.E., Watanabe, M.T., Santos, J.U.M., Trovó, M., Maurity, C. \& Giulietti, A.M. 2016. Flora of the cangas of the Serra dos Carajás, Pará, Brazil: history, study area and methodology. Rodriguésia 67: 1107-1124. 